\title{
The Exploring Nature of Language Learning Strategies (LLSs) and their Relationship with Various Variables with Focus on Personality Traits in the Current Studies of Second/Foreign Language Learning
}

\author{
Seyed Hossein Fazeli \\ Dept., of Linguistics, University of Mysore, India \\ Email: fazeli78@yahoo.com
}

\begin{abstract}
Since Language Learning Strategies (LLSs) have potential to be, "an extremely powerful learning tool" (O'Malley, Chamot, Stewner-Manzanares, Russo \& Kupper, 1985a, p.43), the use of LLSs helps the learners retrieve and store material, and facilitate their learning (Grander \& Maclntyre, 1992), they are sensitive to the learning context and to the learner's internal processing preferences, also they are extremely important part of second/foreign language teaching and learning, and there is relationship between the frequent use of LLSs and achievement in the language (Bremner, 1999; Green \& Oxford, 1995; Oxford \& Burry-Stock, 1995); there is need to understand what are LLSs, in what manner it is possible to teach them to learners, how learners choice and use them, and which variables affect the choice and use of them. A review of the relevant literature shows that there are various variables affect the choice and use of LLSs. Personality traits as one the most predictors, significantly influence success in learning a second language (Gass $\&$ Selinker, 1994). In the current study, the investigator aims to explore the nature of LLSs and their relationship to different variables.
\end{abstract}

Index Terms - language learning strategies, personality traits, language learning, second/foreign language learning

\section{INTRODUCTION}

In the last three decades or so, an important shift has taken place in the field of second/foreign language learning, and researchers have focused mainly on learner's individual factors, that it might be appropriate to comply with Wenden (1985), who reminds us, there is a proverb states "Give a man a fish and he eats for a day. Teach him how to fish and he eats for a lifetime". Applying such proverb in language learning and teaching, tells us that if students are taught strategies of language learning to work out, they will be empowered to manage their own learning. In such way, Ellis (1985) claims that native language speakers use the same strategy types as learners of second/foreign language use. In addition, Chamot, Barnhardt, El-Dinnary and Rubbins (1999) point out that "Differences between more effective learners and less effective learners were found in the number and range of strategies used" (p.166). Therefore, the importance of encouraging using LLSs (LLSs) is undeniable. Moreover even researchers (e. g. O’Malley et al.,1985b; Oxford, 1990; Ellis \& Sinelair, 1989) support the belief that learners who receive learner training, generally learn better than who do not. In addition, there is relationship between the frequent use of learning strategies and achievement in the language (Bremner, 1999; Green \& Oxford, 1995; Oxford \& Burry-Stock, 1995). Therefore, there is claim that use of Language Learning Strategists (LLSs) helps the learners retrieve and store material, and facilitate their learning (Grander \& Maclntyre, 1992).

The studies regarding LLSs are done in three different areas which are the characteristics of LLSs (Oxford, 1990; O’Malley \& Chamot,1990; Wenden \& Rubin,1987); the variables affecting LLSs (Nyikos \& Oxford, 1993; Wharton, 2000); and the effect of strategy training on second/foreign language learning (Oxford, 1990).

From the variables affecting LLSs point of view, since individual differences have been identified as variables influencing language learning outcome (Larsen-Freeman \& Long, 1991; Skehan, 1989); and as it was shown by the study of Marttinen (2008), the high percent of source of learners gain the knowledge is teacher; Horwitz (1988) and Wenden (1991) encourage teachers to discover the prescriptive belief of their own students. And in order to provide successful instruction, teachers need to learn to identify and understand their students' individual difference, and even they need become more aware that their teaching styles are appropriate to their learners' strategies (Oxford \& Cohen, 1992). So interesting patterns of strategy use have been noted in the literature, for instances individuals learn considerable differently in their use of learning strategies (O’Malley, \& Chamot, 1990; Oxford, 1992; Oxford \& Cohen, 1992; Wenden \& Rubin, 1987); in various geographical and cultural settings, a positive relationship between strategy 
use and language was reported (Bruen,2001; Park,1997; Sheorey, 1999); Rasekh and Ranjbari (2003) prove that metacognitive strategy training has a positive impact on enhancing EFL learners' lexical knowledge; learning strategies are essential for developing communication competence(Oxford, 1990); learners do not employ same strategy in all the situations; the use of different strategies is depending on several factors such as personal experiences (Von Glaserefeld, 1996) and general task (Nyikos, 1990); learning style appears to influence strategy use (Ehrman \& Oxford, 1990).

Since LLSs are not innate but are learnable (Oxford, 1994), there are broad justifications have been offered for the evaluation of predictors of LLSs. For instance behavior tendencies reflected in personality traits affect some habits which influence LLSs (Paunonen \& O’Connor, 2007).

Although the idea that the way individuals learn is related to their personality is not new, and since 1990s there has been a growing interest on how personality correlates to the academic performance. Personality has been conceptualized at different levels of breadth (McAdams, 1992), and each of these levels include our understanding of individual understanding. Moreover, individuals are characterized by a unique pattern of traits, and some study shows successful language learners choose strategies to suit their personalities (Oxford \& Nyikos, 1989).

According to cook (2008), to understand scientifically, it must be interesting in personality. In such case, so high progress has been made toward a consensus on personality structure (Costa \& McCare,1992; John, 1990; McCare \& John, 1992), and the other studies regarding the relationship between personality traits and other variables, such as Blickle (1996) prove that Openness to experiences was correlate with interesting to use learning strategies; Ehrman and Oxford (1990) argue that since extroverted students like to interact with others, they learn foreign language better; there is correlation between extraversion and certain linguistic measures (Dewaele \& Furnham, 1999).

\section{REVIEW OF LITERATURE}

As Oxford (1990) points out how LLSs are important in both theoretical and practical aspects of language learning for language learners; since the publication of seminal works "What good learners can teach us" (Rubin, 1975) and "What can we learn from good learners" (Stern, 1975), there have done much valuable works in the field of LLSs.

To our knowledge, a review of the relevant literature considering LLSs shows after decades of research in the related field, LLSs have received considerable attention in the literature. The researchers came to conclusion that vast number of strategies has been reported to be used by language learners (Cohen, 1990) through various used methods such as survey tools and written questionnaire (Gu \& Johnson, 1996; Fan, 2003), interview (Gu, 2003; Parks \& Raymond, 2004), think-aloud or verbal reports (Goh, 1998; Nassaji, 2003), diaries or dialogue journal (Carson \& Longhini, 2002), recolective narratives (Oxford, Lavine, Felkins, Hollaway \& Saleh, 1996). Such measurements are used in the single form of method (separately) or as component methods (single set of methods) based on nature and goals of research works. In the light of these findings, the use of such strategies are varied based on various variables such as second/foreign language proficiency (Chamot, 2005; Chamot \& Kupper,1989; Green \& Oxford,1995; Griffiths, 2003; Hong-Nam \& Learell, 2006; Lan \& Oxford, 2003; Oxford, 1993, 1996; Oxford \& Nyikos, 1989; Shamis, 2003; Wharton, 2000), ethnicity (Ehrman \& Oxford, 1995; Grainger, 1997), self confidence (Chamot, 1994), multilinguality (Ellis, 1994; Nation \& Mclaughlin, 1986), and to be in abroad (Tamada, 1996; Gao, 2006).

Related literature of LLSs includes explanations of some interesting patterns regarding LLSs, such as Marti'nez (1996) argues some features of LLSs which are inferred from the literature: a) They play important role as a facilitator of language learning; b) The learners can choice the LLSs which they like; c) The learners may use the LLSs as problem-solving mechanisms to deal with the process of second/foreign language learning; d) The LLSs can be taught to the learners.

Oxford (1993) and Oxford and Crookball (1989) prove that a) More proficient learners tend to use the LLSs; b) The LLSs use is associated with other variables; c) The LLSs can be taught; d) Both students and teachers can become more aware of the potential of LLSs.

Moreover is that there are some other features for LLSs such as problem orientation, action basis, involvement beyond just cognition, ability to support learning directly or indirectly, degree of observability, level of consciousness, teachibility, flexibility, and influence on strategy choice (Oxford, 1990, p. 11). It must bear in mind that playfulness as one of LLSs" characteristics which is shown as "goal", "purpose", "control" and so on in related studies.

There are important issues in the related literature of LLSs. Firstly, some researchers such as Porte (1988), SinclairBell (1995), and Vann and Abraham (1990) approached LLSs from the point of view of unsuccessful learners; and the other researchers such as Rubin (1975), Stern (1975), and Naiman, Frohlich, Stern and Todesco (1978) concentrate on good learners. Secondly, the role of awareness in strategy use is very complex; and conscious choice is important to LLSs concept. In such case, Kohonen (1992) believes that strategies may become automates. The third issue, language and culture are strongly interwoven, and language is integral part of culture (Bedell \& Oxford,1996; Howard,1996).In such situation, learning a target language would invariably mean learning the culture of the target language (Hall, 1999; Rose, 1999). Therefore, in foreign/second language classrooms, what is learned cannot be separated from cultural influences (Oxford, 1996b).

At finally yet importantly, there is the issue of personality. The studies on individual and personality differences are a central theme in psychology as well as the other areas of social and behavior sciences (Saklofske \& Eysneck, 1998). In such issue there is bag of mixed results. For instance, in the reviewing nine studies regarding L2 success and personality, 
Kiany (1998) found that two of these studies show positive relationship between extraversion and L2 success, three of them have positive relationship between introversion and L2 success, and three of them do not indicate any relationship. Or Robinson, Gabriel and Katchan (1994) found there is positive significant correlation between extraversion and achievement of language learning, but Skehan (1989) proves there is not any relationship. However, there are some more acceptable result such as Ehrman and Oxford (1990) show that inventors are generally uncomfortable with social strategies, and they do not like affective strategies. However, they are very much in favor of metacognitive strategies.

One of important general problematic issues, the issue of typologies that have been formulated for the description and classification of LLSs. Sometimes, one strategy belonging to one category can be classified under another category (Johenson \& Johenson, 1998). In addition Cohen (1998, p.12) presents that they "are not clear-cut". Nevertheless, the taxonomy of Oxford (1990) is the most widely accepted taxonomy. The difference between Oxford's taxonomy and the other ones regarding LLSs is that, Oxford classified heterogeneous strategies into more specific categories (Ehrman, Leaver \& Oxford, 2003). Moreover Oxford's taxonomy links individual strategies and groups of strategies with each of the four language skills (Oxford \& Burry-Stock,1995).

\section{WhAT THE CURRENT STUDIES SHOW ABOUT LLSS}

Since 1975s, dozens of various studies have contributed to our understanding of strategies employed by SL (Second Language)/FL (Foreign Language) learners at the level of adults. Such studies show in order to effect changes in perceptions of the learners' role in the learning process, we need to discover more about what learners do to learn successfully. Moreover such studies show that the best way of going about teaching strategies remain a subject of much debate right up to the present (Brown, 2001) because of use of LLSs is influenced by number of factors (Oxford, 1990), and the frequency and variety of LLSs vary among different individuals and depend on a number of variables (Chamot \& Kupper, 1989).And researches show that students differ considerably in the use of LLSs (O'Malley \& Chamot, 1990; Oxford \& Cohen, 1992). Although, factors such as attitudes, sex, ethnicity and the others have received lesser emphasis in the recent studies of LLSs (Oxford \& Cohen, 1992). But the situation has improved somewhat through the personlogical work of some investigators (Ehrman \& Oxford, 1990).Although still there is need to do more research on personlogical aspects because of the importance of personlogical traits as factors influence LLSs use (Willing, 1987).In this way, the recent studies try to focus more on individual differences in LLSs use (Oxford, 1992; Oxford \& Ehrman, 1993).

A review of the relevant literature considering LLSs show that:

a) Good language learners use a variety of strategies in order to mastery in language skills (O'Malley et al.,1985a); difference between successful and less successful learners is depending on the LLSs they use (Abrahm \& Vann, 1987; Chamot \& El-Dinary, 1990; Cohen \& Cavl canti, 1990); successful learners do not use all same techniques (Stevick, 1989); and there is no single set of strategies appropriate for recommendation to all learners (Gillette, 1987). However there are various variables influencing, such as learners' cultural background (Oxford,1996b; Oxford \& Nyikos, 1989; Politzer,1983; Rubin,1975).Although the welter of research, previous research has failed to have significant importance on individual differences in second/foreign language learning ( Ellis,1985;Griffiths,1991).

b) Since the use of appropriate strategies allow learners to take more responsibilities for own learning, LLSs are seen as particularly important in henchmen of autonomy (Dickinson, 1987).In such manner, one of important objectives in the study of LLSs is to determine effectiveness of LLSs in learning second/foreign language(O’Malley\&Chamot,1990). Therefore, if learners use LLSs efficiently, they can learn by themselves and self-examine their own progress. So having such situation for LLSs can improve learners and enhance their abilities of language. In this way Chamot (2005) comes to conclude that LLSs as procedure which facilitate learning task.

c) The examination of variation in human behavior is referred to as the study of individual differences (Ehrman \& Dornyei, 1998). Such study of individual differences includes many subsets of studies such as the study of personality differences (Hampson \& Colman, 1995), and personality factors that are important in development of linguistic abilities (Ellis, 1985). Psychologically, it is a truism that people are different in many fundamental ways, and learners are individuals, and there are infinitely variables (Skehan, 1989). In this manner Horwitz (1999) points out "language learners are individuals approaching language learning in their own unique way" (p.558). In addition, individuals who are characterized as a particular psychological type, adopt different learning strategies (Brown, 2001).In such situation, the teachers must make the students aware of the range of the strategies they can adopt (Cook, 2008); and they must aware of the relationship between personality and academic performance (Cattel \& Butcher, 1968; Eysenck, 1967).

\section{THE SituATION OF LLSS IN THE RECENT STUdIES}

Since LLSs have potential to be, "an extremely powerful learning tool” (O’Malley et al., 1985a, p.43), and extremely important part of second/foreign language teaching and learning, there is need to understand what are LLSs; in what manner it is possible to teach them to one learner; and how one learner choices and uses them. Such assumption lead that research on LLSs has witnessed profile and vigorous growth, and numerous studies around the world have contributed to both theory and teaching LLSs, which includes "growing interest in defining how learners can take 
charge of their own learning and clarifying how teachers can help students become more autonomous" (Rubin, 1975, p. 15).

One of important issues which Oxford (1994) recommends it, it was that strategy should be somewhat individualized. In addition, in order to provide successful instruction, teachers need to learn to identify and understand their students' individuals' differences. Such reasons cause that some type of key terms shift from teacher to learner, such as "the learner-centered curriculum" (Nunan, 1988) and "learner-centeredness as language education" (Tudor, 1996). In such way, Cook (2008) guides the teachers to make students aware of the range of the strategies they can adopt.

One of the most important problematic issues in the literature of LLSs is that the correlation of personality and preferences for teaching modalities is unexplored yet (Chamorro-Premuzie, Furnham \& Lewis,2007), although the investigation of personality factors is often mentioned to be important for gaining deeper insight into LLSs, and it helps to more understand role of learning strategies which is one of the most important issue as O'Malley and Chamot (1990) remark that it is necessary to clarify "the role of learning strategies in second language acquisition from both an empirical and a theoretical standpoint" ( p.12).

At last it was shown that, various factors might potentially influence a student's choice of LLSs (Gardner \& macIntyer, 1993). In addition, since there is strong relationship between psychological traits and the way that learners use language strategies (Ehraman \& Oxford, 1990), psychological traits can play most important role in the field of LLSs.

\section{THE RELATIONSHIP BETWEEN LLSS AND DIFFERENT VARIABLES IN THE CURRENT STUDIES}

The LLSs have been one of the most researched topics in the fields of second/foreign language education since Rubin (1975) wrote on the subject. The related studies include research on the relationship between LLSs use and various variables.

Such research includes the studies regarding the relationship between LLSs and gender, which show language use and gender have mixed results (Griffiths, 2004). Some studies show that there is difference of LLSs use based on the gender (Ehraman \& Oxford, 1989; Green \& Oxford, 1995; Oxford \& Nyikos, 1989). In such related studies it was found that female students reporting all or some of six groups of LLSs more frequently than male (Dreyer \& Oxford, 1996; Ghasedy,1998; Goh \&Foong ,1997; Green \& Oxford,1995; Hong-Nam \&Learvell,2006; Lan \& Oxford,2003; Lee \& Oh, 2001; Oxford,1989; Oxford,Nyikos \& Ehrman,1988; Politzer,1983).However the other studies prove that gender does not affect LLSs use (Griffiths, 2003; Lee \& Oxford, 2008; Ziahossein \& Salehi, 2008).

Regarding the effect of students' majors of study (fields) on strategy use, there are mixed results. Some studies found significant influences of students' majors of study (fields) on students' strategy use (Dreyer \& Oxford, 1996; Oxford \& Nyikos, 1989); however, the other studies prove no significant difference regarding the effect of students' majors of study (fields) on choice of strategy and strategy use (Ghasedy, 1998; Lee \& Oxford, 2008).

In the case of effect of a second/foreign proficiency on strategy use, the most of the related research show that proficiency effect strategy use (e.g. Ghadesy, 1998).

The last case of effect of age on LLSs is "far from clear or conclusive" (Spolkey, 1989, p.92).

Alongside the field of LLSs, personality of individuals are affected through various variables such as culture(Markus \& Kitayama,1998), genetic and environmental factors(Eysenck \& Eysenck, 1985), sex differences(Budaev, 1999; Costa \& McCare, 1992), and ethnicity (Griffiths, 1991).

\section{RATIONALE FOR THE RESEARCH ON PERSONALITY TRAITS IN RELATION WITH LLSS}

A review of the relevant literature shows that personality traits significantly influence success in learning a second language (Gass \& Selinker, 1994) and understanding the reasons for individual differences in levels of learning has always been a concern of researchers in the related fields. In this way, there are four soundest reasons to assess the relationship between LLSs and personality traits are: a) Learners need to know how to learn; b) Learners can provide training on how to improve learning of language; c) Teachers need to learn how to facilitate the process of learning; d) Knowing about personality can help the learners to learn more effectively.

In addition, there is evidence to show particular variables facilitate learning of a second/foreign language. In more specific examples, for instance, personality factors are important in development of linguistic abilities (Ellis, 1985), and even personality traits reflect what an individual will do (Furnham \& Chamorro-Premuzic, 2004). Therefore, such variables may take into consideration when forming classes. Such findings alongside this assumption that Language Learning Strategy is a key factor affecting learners' rate of language learning and the ultimate level of language proficiency (Ellis, 1994), cause the researchers to have this important premise that finding the relationship between LLSs and personality traits is important, if the learners of second/foreign language learners wish to learn effectively.

\section{LIMITATION OF THE RESEARCH WORKS IN THE STUDY OF LLSS}

Generally speaking, there are some difficulties inherent in endeavor to conduct any research work on the learners of a second/foreign language. Such difficulties are as the results of methods (e. g. measurement issues, sampling issues), type of instrumentations (e.g. exclusive reliance on self-report responses to the questionnaires, ambiguity in the 
questionnaire item wording, response style bias), and the other variables used in conducting descriptive type of research (Ellis, 1985).

Since all the education quasi-research deal with living human beings are occur out of laboratory conditions have limitations (Gall, Gall \& Borg, 2003). Such limitations include limitations that are related to questionnaires, sample, second/foreign proficiency test, type of research, statistical method, culture and nationality, environment, gender, comprehensive operational definitions.

Regarding the issue of questionnaire, although survey studies have been very illuminating and have yielded important results, the first limitation is that measuring of LLSs is done by using questionnaires. Since the questionnaires are self-report and single source of information, it is not clear whether the participants actively used the LLS which they indicated. Their response may not be just their beliefs and thoughts that they have about their use of strategies. In such way, in order to investigate students' actual use of LLSs, it should be some research method to corroborate results of questionnaire. For instance the researchers must observe classes, use think-aloud procedure (introspection), interview, and so forth. The second, there are may also have been some unclear points in questionnaire itself such as "Never" to "Always" may have been fuzzy because the interpretation of these scales can change according to context (Hatch \& Brown, 1995), and the vagueness of wording has been another persistent problem in using questionnaire $(\mathrm{Gu}, \mathrm{Wen} \&$ $\mathrm{Wu}, 1995)$. The third issue, difficulty in cross-language research involves translation of the questionnaires. The fourth issue, questionnaires may not able to cover all the dimension of learners' LLSs and there is not deep insight. The fifth issue, although the learners' use of strategy is dynamic across times (Schmitt, 1997), questionnaires made strategy use to be as a static variable. Moreover, some questionnaires such as Strategy Inventory for Language Learning (SILL) which is designed by Rebecca L. Oxford (1990), do not describe in detail the LLSs a student uses in responses to any specific language task.

Regarding the limitation related to sample of participants, the sample may not be representative the population in general. However, researchers often selected a convenience sample in order to complete a study (Gall, Gall \& Borg, 2003).

Regarding the limitation related to second/foreign language proficiency, determining proficiency in language learning for speakers of other languages is not easy endeavor, and has been discussed by experts (Bachman, 1990; Farhady, 1982). For instance some studies used proficiency test scores (Dreyer \& Oxford, 1995; Green \& Oxford, 1995) and the others used self-rating (Wharton, 2000).

Since longitudinal research is more complicated and much slower, short period of study is chosen. As Ellis (1994, p.556) "sorely need" to have longitudinal research on LLSs, and as Chaudron (2003) (as citied in Griffiths, 2006) points out there is rarely longitudinal research in such case.

Regarding the limitations related to statistical methods, there is an important issue in the statistical procedures, that it is the reliability estimates of internal consistency may not be appropriate to measure something that could fluctuate in short period of time which is common the most of studies. The test-retest reliability measure is better indicator of reliability in such type of research. The second limitation is response biases. As it is known there are three prominent types of response biases, which are social desirable response, acquiescence, and extremely response bias (Herk, Poortinga \& Verhallen, 2004).

Regarding the limitation related to culture, as Eliason (1995) discuses both culture and language affect the questionnaires. In addition in foreign/second language classrooms, what is learned cannot be separated from cultural influences (Oxford, 1996b).And the second issue, problem in cross-cultural studies is the style of response bias. In such case, the western-based of the questionnaires can affect the whole results of many studies in the way that maybe some different results would be suggested.

Generally speaking, one of the problematic issues that can be as a limitation is the lack of the comprehensive operational definitions.

\section{CONCLUSION}

Like other theories, the theory of LLSs has evolved. In such theory, particular approaches, methods, strategies, techniques were developed. Research on the related literature of LLSs, shows that LLSs has a history of only thirty years which is much sporadic (Chamot, 2005). Moreover, recently such strategies have been the focus of specific research (Oxford, 1990), and much of the research was descriptive. In addition, at the early researches on LLSs, there was not empirical research on nature of learning strategies and their influence on second language acquisition (O’Malley \& Chamot, 1990). In addition the development research on LLSs was based on early studies which were researched on good language learners (e. g. Rubin,1975).Such studies conducted on good language learners shows that good language learners have much to tell us about LLSs(Rubin,1975).

Past studies regarding LLSs have contributed to a voluminous archive of evidence pointing to the conclusion that there are many problematic issues have been arisen in the field of LLSs which must be the goal of consideration by the second/foreign language researchers. One of the main problematic issues is a plethora of terminology, dearth of clear understanding of terms, the lack of possibility to neatly draw line between them, and their applications in the field of language learning. However there are considerable progress has occurred in this field regarding the classification of LLSs (Ellis,1994). And even it is clearly to find comprehensive taxonomies (O'Malley \& Chamot, 1990; Ellis; 1994; 
Oxford, 1990). The second problematic issue is that the previous research has failed to have significant importance on individual differences in second language learning (Ellis, 1985; Griffiths, 1991). Although the findings regarding the effectiveness of strategy training are rather mixed (Griffiths, 2004), but since there are studies which show that learners who received LLSs, generally learn better those learners who do not (Ellis \& Sinckair, 1989; Oxford, 1990), the research on LLSs will continue to develop the researchers of second/foreign language acquisition/learning. In addition, research on LLSs continues in various directions for better understanding of both learning and teaching of language. Still there is not logical and well-accepted system for describing of strategy (Oxford, 1994).

The third problematic issue, individuality characteristics of teachers and their beliefs as factors often influence the effectiveness of the teaching/learning process (Richards, 1996), and teachers are "pivotal in the enterprise of teaching /learning situation" (Freeman \& Richards, 1996, p.1). The teachers are generally are not aware of their students' learning strategies (Martinez, 1995; O’Malley et al 1985a), and their assumptions about their students' strategies are not correct (Hosenfeld, 1976), and even they have quite contrary to each other (Griffiths \& Parr, 2001). In such way, it is difficult for teachers to accommodate various LLSs within the class and still cover required curriculum. Moreover, since some strategies are useful only for task (Oxford, 1989); sometime teaching the use of LLSs becomes more difficult if teachers do not have the materials appropriate to their classrooms (O'Malley \& Chamot, 1990).

The fourth problematic issue, as Brown (2001) and Ellis (1985) believe, since there are abstract nature for many concepts, and problems of identification and measurements, it is not easy to study personality variables in second language learning contexts.

The fifth problematic issue, there is evidence to show particular variables facilitate learning of a second/foreign language. One of these variables is personality traits of the learners that are internal factors. However, regarding the results of the effects of personality traits on LLSs, and the relationships between LLSs and personality traits, there is lack of consensus in the results, inclusive or even contradictory results. For instance, there is a bag of mixed results about the correlation between extraversion and achievement of language learning, for example Robinson, Gabriel and Katchan (1994) found there is positive significant correlation, or Reiss(1983) found extraversion has significant correlation with successful language learning, but Skehan (1989) shows there is not any relationship. In such way, such theories are different and sometimes they are conflicting, and such assumptions may have the potential to affect and lead to different suggested results.

The sixth problematic issue, as Brown (1991) states "a language is part of culture and culture is part of a language" (p.165), there is belief that explicit teaching of target culture can improve non-native speaker linguistic skills (Hall, 1999).In such case, there are some problems arise in the mentioned field regarding teaching and learning of particular parts of the target culture when it is varied from the culture of L1. Such problems are not focused in the current studies.

The seventh problematic issue, with this feedback in mind that as Brown (1991) states "after a century of modern approach to language teaching, we have learnt that there is no single method that will work for all people in all situations" (p.138), and Ellis (1994) states that "veritable plethora of individual learner variable which researchers have been identified as influencing learning outcomes" (p.472), one of these variables, the general principal that learners need to play an active role in learning process (Horwitz, 1999)which has become widely accepted (although the general concept of using strategies to enhance learning is not new).But as Selinker (1972, p.213) emphasizes that " $a$ theory of second language learning does not provide a central place for individuals differences among learners" (author's italics).

The eighth problematic issue, the teachability of LLSs is by no means universally accepted. Although Chamot, Barnhardt, El-Dinnary and Rubbins (1999) state "differences between more effective learners and less effective learners were found in the number and range of strategies used, in how the strategies were applied to the task ,and in whether they were appropriate for the task" (p.166). In addition there are some general theoretical underpinnings that no single set of strategies appropriate recommendation to all learners (Gillette, 1987), LLSs as one of the most factors for individual differences in second language acquisition (Chamot,2005); as hinted in the previous sections, in the field of second/foreign learning and teaching, the focus has been shifted from teaching to learning; and the most important that although there has been extensive research on LLSs, but still there is lack of research conducted on some special aspects of learners' LLSs, such as base on which trait of personality, learners report doing particular LLSs to achieve success in language learning, and which patterns of reported use of LLSs are according to personality traits.

The ninth problematic issue, various valuable research works on variables in the relationship with LLSs have been done and continues to be done, but the previous research in the field of LLSs face with difficult questions which akin to the age-old riddle about the chicken and egg which comes first, because since learners can vary greatly from each others in their approach to learning, there is no consensus on what constitute LLSs in second/foreign language learning.

One of important concluding remarks in past studies, it is that interaction refers to communication between individuals (Ellis, 1999), and interaction provides learners with opportunities to gain receive comprehensive input (Gass, 1997) and make changes in their linguistic output (Swain, 1995). Moreover Nunan (1988) and Rogers (1983) claim that teaching and learning processes are the results of interaction between teachers and learners.

The last but not least, the factors in the use of LLSs can be categorized as: a) Learner's characteristics, b)Teacher's characteristics, c) Methodology and Materials. 


\section{REFERENCES}

[1] Abraham, R.G. \& R. J. Vann (1987). Strategies of two language learners: A case study. In A. Wenden \& J. Rubin (eds.), Learner strategies in language learning. Englewood Cliffs, NJ: Prentice Hall, 85-102.

[2] Bachman, L.F. (1990). Fundamental considerations in language testing. Oxford: Oxford University Press.

[3] Bedell, D.A. \& R.L. Oxford (1996). Cross-cultural comparisons of language learning strategies in the People's Republic of China and other countries. In R.L. Oxford (ed.), Language learning strategies around the world: Cross-cultural perspectives. Honolulu, HI: University of Hawai'i Press, 47-60.

[4] Blickle, G. (1996). Personality traits, learning strategies and performance. European Journal of Personality 10,337-352.

[5] Bremner, S. (1999). Language learning strategies and language proficiency: Investigating the relationship in Hong Kong. Canadian Modern Language Review 55,490-514.

[6] Bruen, J. (2001). Strategies for success: Profiling the effective learner of German. Foreign Language Annals 34.3, $216-225$.

[7] Brwon, H. D. (1991). Breaking the language barrier: creating your own pathway to success. Yarmouth, ME: Intercultural Press.

[8] Brwon, H. D. (2001). Principles of language learning and teaching. Englewood Cliffs, NJ: Prentice Hall.

[9] Budaev, S.V. (1999). Sex differences in the big five personality factors: Testing an evolutionary hypothesis. Personality and Individual Differences 26, 801-813.

[10] Carson, J.G. \& A. Longhini. (2002). The big five personality dimensions and job performance focusing on learning styles and strategies: A dairy study in an immersion setting. Language Learning 52.2, 401-438.

[11] Cattel, R. B. \& H. Butcher (1968). The prediction of achievement and creativity. New York: Bobbs-Merrill.

[12] Chamorro-Premuzie, T., A. Furnham \& M. Lewis (2007). Personality and approaches to learning predict preference for different teaching method. Learning and Individual Differences 17, 241-250.

[13] Chamot, A.U. (1994). A model for learning strategies instruction in foreign language classroom. In J. Alatis(ed.), Georgetown University Round Table on Language and Linguistics. Washington, D.C.: Georgetown University Press, 323-336

[14] Chamot, A.U. \& B.P. El-Dinary. (1990). Children's learning strategies in language immersion classroom. The Modern Language Journal 83.3, 319-338.

[15] Chamot, A.U. (2005).Language learning strategy instruction: Current issues and research. Annual Review of Applied Linguistics 25, 112-130.

[16] Chamot, A.U., S. Barnhardt, P. B. El-Dinnary \& J. Rubbins. (1999). The learning strategies handbook. New York: Longman.

[17] Chamot, A. \& L. Kupper (1989). Learning strategies in foreign instruction. Foreign Language Annals 22, 13-24.

[18] Cohen, A.D. (1990). Language learning: Insights for learners, teachers, and researchers. Boston, Mass.: Heinle and Heinle Publishers.

[19] Cohen, A. D. \& M. C. Cavalcanti. (1990). Feedback on composition: Teacher and student verbal reports. In B. Kroll (Ed.), Second language writing: Research insights for the classroom. Cambridge: Cambridge University Press, 155-177.

[20] Cook, V. (2008). Second language learning and language teaching. London: Edward Arnold.

[21] Costa, P.T. \& P. R. McCare. (1992). Professional manual for the NEO-PI-R and NEO-FFI. Odessa, FL: Psychological Assessment Resources.

[22] Dewaele, J. \& A. Furnham. (1999). Extraversion: The unloved variable in applied linguistic research. Language Learning 49, 509-514.

[23] Dickinson, L. (1987). Self-instruction in language learning. Cambridge: Cambridge University Press.

[24] Dreyer, C. \& R. L. Oxford. (1996). Learning strategies and other predictors of ESL proficiency among Afrikaans-speakers in South Africa. In Oxford, R.L. (ed.). Language learning strategies around the world: Cross-cultural perspectives. Mona: University of Hawaii, 61-74.

[25] Ehrman, M.E. \& Z. Dornyei. (1998). Interpersonal dynamics in second language education: the visible and invisible classroom. Thousand Oaks, Calif: Sage Publications.

[26] Ehrman, M.E., B. L. Leaver \& R. L. Oxford. (2003). A Brief overview of individual differences in second language learning. System 31, 313-330.

[27] Ehrman, M. \& R. L. Oxford. (1990). Adult language learning styles and strategies in an intensive training setting. The Modern Language Journal 74.3, 311-327.

[28] Eliason, P.A. (1995). Difficulties with cross-cultural learning-style assessment. In J.M. Reid (ed.), Learning styles in the ESL/EFL classroom. New York: Heinle \& Heinle Publishers, 19-33.

[29] Ellis, R. (1985). Understanding second language acquisition. Oxford: Oxford University Press.

[30] Ellis, R. (1994).The study of second language acquisition. Oxford: Oxford University Press.

[31] Ellis, R. (1999).Learning a second language through interaction. Philadelphia: John Benjamins.

[32] Ellis, R., \& Sinckair, B. (1989). Learning to learn. Cambridge: Cambridge University Press.

[33] Eysenck, H. J.(1967). The biological basis of personality. New York: Springfield.

[34] Eysenck H.J. \& M. W. Eysenck (1985). Personality and individual differences: a natural science approach. New York: Plenum Press.

[35] Fan, M.Y. (2003). Frequency of use perceived usefulness, and actual usefulness of second language vocabulary strategies: A study of Hong Kong learners. Modern Language Journal 87.2, 222-241.

[36] Farhady, H. (1982). Measures of language proficiency from the learner's perspective. TESOL Quarterly 16, 73-59.

[37] Freeman, D. \& J. C. Richards (eds.) (1996). Teacher learning in language teachings. Cambridge: Cambridge University Press.

[38] Furnhum, A. \& T. Chamorro-Premuzic (2004). Personality and intelligence as predictors of statistics examination grades. Personality and Individual Differences 37, 943-955.

[39] Gall, M.D., J. P. Gall \& W. R. Borg (2003). Educational research: An Introduction (7 ed.). Boston: Allyn and Bacon.

[40] Gao, X. (2006). Understanding changes in Chinese students' uses of learning strategies in China and Britain: A socio-cultural re-interpretation. System 34, 55-67. 
[41] Gardner, R.C. \& P. R. MacIntyre. (1992). A student's contribution to second language learning: Part I, cognitive variables. Language Teaching 25.2, 211-220.

[42] Gardner, R.C. \& P. R. MacIntyre. (1993). A student's contribution to second language learning: Part II, affective factors. Language Teaching 26, 1-11.

[43] Gass, S.M. (1997). Input, interaction, and the second language learner. Mahwah, NJ: Lawrence Erlbaum.

[44] Gass,S. \& L. Selinker (1994). Second language acquisition: An introductory course. Hillsdale, NJ: Lawrence Erlbaum.

[45] Ghadessy, M. (1998). Language learning strategies of some university students in Hong Kong. Estudios Inglesese de la Universidad Complutense.6, 101-128. http://revistas.ucm.es/fll/11330392/articulos/EIUC9898110101A.PDF (accessed 20/03/2010).

[46] Gillette, B. (1987). Two Successful Language Learners: An Introspective Approach. In C. Faerch \& G. Kasper. (eds.), Introspection in Second Language Research. Philadelphia, Clevedon: Multilingual Matters, 268-279.

[47] Goh, C.M. (1998). How ESL learners with different listening abilities use comprehension strategies and tactics. Language Teaching Research 2.2, 124-147.

[48] Goh, C.M. \& K. P. Foong. (1997). Chinese ESL students' learning strategies: A look at frequency, proficiency, and gender. Hong Kong Journal of Applied Linguistics 2, 39-53.

[49] Grainger, P. R. (1997). Language-learning strategies for learners of Japanese: investigating ethnicity. Foreign Language Annals 30.3, 378-385.

[50] Green, J.M. \& R. L. Oxford. (1995). A closer look at learning strategies, L2 proficiency, and gender. TESOL Quarterly 29.2, 261-297.

[51] Griffiths, C. (1991). Personality and second-language learning: theory, research, and practice. http://www.eric.ed.gov/PDFS/ED367167.pdf (accessed 10/03/2010).

[52] Griffiths, C. (2003). Patterns of language learning strategy use. System 31.(3, 367-383.

[53] Griffiths, C. (2004). Language learning strategies: theory and research. Occasional Paper (1), http://www.crie.org.nz/research_paper/c_griffiths_op1.pdf (accessed 28/03/2010).

[54] Griffiths, C. (2006). Strategy development and progress in language learning. Prospect 21.3, 58-75.

[55] Griffiths, C. \& M. Parr. (2001). Language-learning strategies: theory and perception. ELT Journal 55.3, $247-254$.

[56] Gu, P.Y. (2003). Fine brush and freehand: The vocabulary-learning art of two successful Chinese EFL learners. TESOL Quarterly 37.1, 73-104.

[57] Gu, P.Y. \& R. K. Johnson. (1996). Vocabulary learning strategies and language learning outcomes. Language Learning, 46.4, 643-679.

[58] Gu,Y., Q.Wen \& D.Wu. (1995). How often is Often? Reference Ambiguities of the likert-scale in Language Learning Strategy Research. Occasional Papers in English Language Teaching (vol.5). ELT Unit, Chinese University of Hong Kong, 19-35.

[59] Hall, J. K. (1999). A prosaics of interaction: The development of interactional competence. In E. Hinkel (ed.), Culture in second teaching and learning. Cambridge University Press, 137-151.

[60] Hampson, S.E. \& A. E. Colman (1995). Individual differences and personality. New York: Longman.

[61] Hatch, E. \& C. Brown (1995). Vocabulary, semantics, and language education. Cambridge: Cambridge University Press.

[62] Hong-Nam, K. \& A. G. Leavell (2006). Language use of ESL students in an intensive English learning context. System 34, 399-419.

[63] Herk, V.P.,Y. H. Poortinga \& T. M. M.Verhallen. (2004). Response style in rating scales: Evidence of method bias in data from six EU countries. Journal of Cross-Cultural Psychology 35. 3, 346-360.

[64] Horwitz, E.K. (1988). The beliefs about language learning of beginning university foreign language students. Modern Language Journal 72.13, 283-294.

[65] Horwitz, E.K. (1999). Cultural and situational influences on language learners' beliefs about language learning: a review of BALLI studies. System 27, 557-576.

[66] Hosenfeld, C. (1976). Learning about learning: Discovering our students' strategies. Foreign Language Annals 9, 117-129.

[67] Howard, M.C. (1996). Contemporary cultural anthropology (5th ed.). New York: HarperCollins College Publishers.

[68] John, O.P. (1990). The big five factor taxonomy: Dimensions of personality in the nature language and in the questionnaire. In L.A. Pervin(ed.), Handbook of Personality: Theory and Research. New York: Guilford Press, 66-100.

[69] Johnson, K. \& H. Johnson. (1998). Encyclopedic dictionary of applied linguistics: A handbook for language teaching. Oxford: Blackwell.

[70] Kiany, G.R. (1998). English proficiency and academic achievement in relation to Extraversion: a preliminary study. International Journal of Applied Linguistics 8.1, 113-129.

[71] Kohonen, V. (1992). Experiential language learning: Second language learning as cooperative learner education. In D. Nunan (ed.), Collaborrative Language Learning and Teaching. Cambridge: Cambridge University Press, 14-39.

[72] Lan, R. \& R. L.Oxford. (2003). Language learning strategy profiles of elementary school students in Taiwan. International Review of Applied Linguistics in Language Teaching 41, 339-379.

[73] Larsen-Freeman, D. \& M. H. Long. (1991). An Introduction to second language acquisition Research. New York: Longman.

[74] Lan, R. \& R. L. Oxford (2003). Language learning strategy profiles of elementary school students in Taiwan. International Review of Applied Linguistics in Language Teaching 41, 339-379.

[75] Lee, H. \& J. Oh. (2001). The relationship between attitudes and proficiency in learning English. English Teaching 55.4, 389409.

[76] Markus, H.R. \& S. Kitayama. (1998). The cultural psychology of personality. Journal of Cross Cultural Psychology 29.1, 6387.

[77] Marti'nez, I.M.P. (1995). A study of the learning strategies used by secondary school and university students of English in Spain. Revista Alicantina de Estudios Ingleses 8,177-193. http://revistas.ucm.es/fll/11330392/articulos/EIUC9898110101A.PDF(accessed 20/03/2010). 
[78] Marti'nez, I.M.P. (1996). The importance of language learning strategies in foreign language teaching. Cuadernos de Filologia Inglesa, 5(1), 103-120. http://dialnet.unirioja.es/servlet/fichero_articulo?codigo=1325566\&orden=0 (accessed 20/03/2010).

[79] Marttinen, M. (2008). Vocabulary learning strategies used by upper secondary school Students studying English as a second language. M.A. Dissertation. (accessed 15/03/2010) https://jyx.jyu.fi/dspace/bitstream/handle/123456789/18447/URN_NBN_fi_jyu200803261288.pdf?sequence=1

[80] McAdams, D.P. (1992). The five-factor model in Personality: A critical appraisal. Journal of Personality, 60, 329-361.

[81] McCare, R.R. \& O. P. John. (1992). An Introduction to the five-factor model and its application. Journal of Personality 60.2, $175-215$.

[82] Naiman, N., M. Frohlich, H. Stern \& A. Todesco. (1978).The good language learner. Research in Education series, 7. Toronto: The Ontario Institute for Studies in Education.

[83] Nassaji, H. (2003). L2 vocabulary learning from context: Strategies, knowledge sources, and their relationship with success in L2 lexical inferencing. TESOL Quarterly 37.4, 645-670.

[84] Nation, R. \& B. McLaughlin. (1986). Experts and novices: an information-processing approach to the 'good language learner' problem. Applied Psycholinguistics 7, 41-56.

[85] Nunan, D. (1988). The learner-centered curriculum. Cambridge: Cambridge University Press.

[86] Nyikos, M. (1990). Sex-related differences in adult language learning: socialization and memory factors. The Modern Language Journal 74.3, 273-287.

[87] Nyikos, M. \& R.L. Oxford. (1993). A factor analytic study of language learning strategy use: Interpretations from informationprocessing theory and social psychology. Modern Language Journal 77, 11-22.

[88] O'Mally, J.M. \& A. U. Chamot. (1990). Learning strategies in second language acquisition. Cambridge: Cambridge University Press.

[89] O’Mally, J.M., A. U.Chamot, G. Stewner-Manzanares, L. Kupper \& R. P. Russo (1985a). Learning strategies used by beginning and intermediate ESL students. Language Learning 35.1, 21-46.

[90] O’Mally, J.M., A. U. Chamot, G. Stewner-Manzanares, R.P. Russo \& L. Kupper. (1985b). Language strategy application with students of English as a second language. TESOL Quarterly 19.13, 557-584.

[91] Oxford, R.L. (1989). Use of language learning strategies: A synthesis of studies with implications for students training. System $17.2,235-247$.

[92] Oxford, R.L. (1990). Language learning strategies: What every teacher should know. Boston: Heinle \& Heinle.

[93] Oxford, R.L. (1992). Instructional implications of gender differences in second/foreign language learning styles and strategies. Applied Language Learning 4. 1\& 2, 65-94.

[94] Oxford, R.L. (1993). Language learning strategies in nutshell: Update and ESL suggestions. TESOL Journal 2, 18-22.

[95] Oxford, R.L. (1994). Language learning strategies: An update. Online Resources: Digest. http://www.cal.org/resources/digest/oxford01.html(accessed 08/03/2010).

[96] Oxford, R.L. (1996a). Employing a questionnaire to assess the use of language learning strategies. Applied Language Learning $7.1 \& 2,25-45$.

[97] Oxford, R.L. (ed.) (1996b). Language learning strategies around the world: Cross-cultural perspectives. Honolulu, HI: University of Hawaii Press.

[98] Oxford, R. L. \& J. Burry-Stock (1995). Assessing the use of language learning strategies worldwide with the ESL/EFL version of the Strategy Inventory for Language Learning (SILL). System 23.1, 1-23.

[99] Oxford, R.L., \& A. Cohen (1992). Language learning strategies: Crucial issues of concept and classification. Applied Language Learning 3. $1 \& 2,1-35$.

[100] Oxford, R.L. \& D. Crookball. (1989). Research on language learning strategies: methods, findings, and instructional issues. The Modern Language Journal 73.4, 404-419.

[101] Oxford, R. L. \& M. Ehrman, M. (1993). Second language research on individual differences. Annual Review of Applied Linguistics 13, 188-205.

[102] Oxford, R.L., R. Z. Lavine, G. Felkins, M E. Hollaway \& A. Saleh. (1996). Telling their stories: Language students use diaries and recollection. In R.L. Oxford (ed.), Language learning strategies around around the world: Cross-cultural perspective. Honolulu, HI: University of Hawaii Press, 199-34.

[103] Oxford, R.L. \& M. Nyikos. (1989). Variables affecting choice of language learning strategies by university students. Modern Language Journal 73.3, 291-300.

[104] Oxford, R.L., M. Nyikos \& M. E. Ehrman. (1988). Vive la differences? reflection on sex differences in use of language learning strategies. Foreign Language Annual 21.4, 321-328.

[105] Park, G. (1997). Language learning strategies and English proficiency in Korean university students. Foreign Language Annals 30, 211-221.

[106] Parks, S. \& P. M. Raymond. (2004). Strategy use by non-native English speaking students in an MBA program: Not business as usual. Modern Language Journal 88.3, 374-389.

[107] Paunonen, S.V. \& M. C. O’Connor. (2007). Big Five personality predictors of post-secondary academic performance. Personality and Individual Differences 43, 971-990.

[108] Politzer, R. (1983). An exploratory study of self-reported language learning behaviors and their relation to achievement. Studies in Second Language Acquisition 6, 54-65.

[109] Porte, G. (1988). Poor language learners and their strategies for dealing with new vocabulary. ELT Journal 42.3, 167-171.

[110] Rasekh, Z.E. \& R. Ranjbari, R. (2003). Metacognitive strategy training for vocabulary learning. TESL-EJ 7.2.

[111] Reiss, M.A. (1983). Helping the unsuccessful language learner. Canadian Modern Language Review 39.2, 257-266.

[112] Richards, J.C. (1996). Teachers maxims in language learning. TESOL Quarterly 30.2, 281-296.

[113] Robinson, D., N. Gabriel \& O. Katchan. (1994). Personality and second language learning. Personality and Individual Differences 16.1, 143-157. 
[114] Rose, K.R. (1999). Teachers and students learning about requests in Hong Kong. In E. Hinkel (ed.), Culture in second language teaching and learning. Cambridge: Cambridge University Press, 167-180.

[115] Rogers, C. R. (1983). Freedom to Learn. Columbus, Ohio: Merril.

[116] Rubin, J. (1975). What the 'good language learners' can teach us. TESOL Quarterly 9.1, 41-51.

[117] Saklofske, D.H. \& S. B. G. Eysneck (eds.) (1998). Individual differences in children and adolescents. New Brunswick, NJ: Transaction Publishers.

[118] Schmitt, N. (1997). Vocabulary learning strategies. In N. Schmitt \& M. McCarthy (eds.), Vocabulary: Description, acquisition and pedagogy. Cambridge: Cambridge University Press, 199-227.

[119] Selinker, L. (1972). Interlanguage. International Review of Applied Linguistics 10, 209-230.

[120] Sheorey, R. (1999). An examination of language learning strategy use in the setting of an indigenized variety of English. System 27, 173-190.

[121] Shmais, W.A. (2003). Language learning strategy use in Palestine. TESL-EJ 7.2, 1-17.

[122] Sinclair-Bell, J. (1995). The relationship between L1 and L2 literacy: Some complicating factors. TESOL Quarterly 29.4, 687704.

[123] Skehan, P. (1989). Individual differences in second-language learning. London: Edward Arnold.

[124] Spolsky, B. (1989). Conditions for second language learning. Oxford: Oxford University Press.

[125] Stern, H.H. (1975). What can we learn from the good language learner? Canadian Modern Language Review 34, $304-318$.

[126] Stevick, E.W. (1989). Success with foreign language: seven who achieved it and what worked for them. London: Prentice Hall.

[127] Swain, M. (1995). Three functions of output in second language learning. In G. Cook \& B. Seidhofer (eds.), Principle and practice in applied linguistics: Studies in honour of H.G. Widdowsom. Oxford: Oxford University Press, 125-144.

[128] Tamada, Y. (1996). Japanese learners' language learning strategies: The relationship between learners' personal factors and their choices of language learning strategies. http://www.eric.ed.gov/PDFS/ED401746.pdf (accessed 08/03/2010).

[129] Tudor, I. (1996). Learner-centeredness as language education. Cambridge: Cambridge University Press.

[130] Vann, R.J. \& R. G. Abraham (1990). Strategies of unsuccessful language learners. TESOL Quarterly 24.2, 177-198.

[131] Von Glaserfeld, E. (1996). Introduction: aspects of constructivism. In C.T. Fosnot (ed.), Constructivism: Theory, perspectives, and practice. New York: Teacher College Press.

[132] Wenden, A. (1985). Learner strategies. TESOL Newsletter 19.5, 1-7.

[133] Wenden, A. \& J. Rubin (eds.) (1987). Learner strategies in language learning. Englewood Cliffs, New York: Prentice/Hall International.

[134] Wharton, G. (2000). Language learning strategy use of bilingual foreign language learners in Singapore. Language Learning $50.2,203-243$.

[135] Willing, K. (1987). Language strategies as information management. Prospect 213, 273-291.

[136] Ziahosseini, S.M. \& M.Salehi. (2008). An Investigation of the relationship between motivation and language learning strategies. Pazhouhesh-e Zabanha-ye Kareji 41 (Special Issue), 85-107.

Seyed Hossein Fazeli received his M.A. degree in linguistics from university of Mysore in 2006.Currently he is pursuing his Ph.D. in program in linguistics at university of Mysore, India. His interest includes Language Learning Strategies in general and English Language Learning Strategies in specific study of languages. 